\title{
ANALISIS TINGKAT KESULITAN BELAJAR MATEMATIKA SECARA DARING TERHADAP HASIL BELAJAR PESERTA DIDIK
}

\author{
SYLVIA LILY \\ SMP Negeri 202 Jakarta \\ Email : sylvialily17769@gmail.com
}

\begin{abstract}
ABSTRAK
Pelajaran matematika untuk sebagian siswa bukanlah hal yang menyenangkan, itu disebabkan dasar pembelajaran matematika yang didapatkan siswa tersebut sangat kurang sehingga menimbulkan rasa kurang percaya diri dalam belajar . Apalagi pembelajaran matematika yang dilakukan secara daring membuat sebagian siswa kesulitan untuk mempelajarinya. Untuk itu perlu dilakukan tinjauan ilmiah sehingga dapat membantu siswa dalam mengatasi kesulitan belajar matematika secara daring. Kesulitan yang dialami siswa akan menghambat proses pembelajaran selanjutnya sehingga tujuan pembelajaran tidak akan tercapai. Kesulitan yang dialami siswa akan menghambat proses pembelajaran selanjutnya sehingga tujuan pembelajaran tidak akan tercapai. Penulisan artikel ini bertujuan untuk menemukan kesulitan yang dialami siswa dan menemukan cara untuk mengatasinya. Penelitian ini dilakukan terhadap siswa kelas 8 pada semester genap di Sekolah Menengah Pertama Negeri 202 Jakarta terhadap mata pelajaran matematika.Metode penelitian yang digunakan adalah penelitian kuantitatif dengan metode survey, dengan memberikan instrument kepada siswa untuk mendapatkan fakta yang ada di SMPN 202. Dari hasil survey penelitian didapatkan beberapa penyebab dari kesulitan belajar matematika secara daring yang menyebabkan hasil belajar akademik siswa tidak sesuai standar. Hal ini disebabkan beberapa hal yang berasal dari factor internal dan eksternal. Dari faktor internal, siswa sulit memahami materi matematika disebabkan kemampuan berpikir yang agak lambat. Sedangkan dari factor eksternal, siswa tidak ada teman diskusi/ bertanya saat mengalami kendala dalam pelajaran matematika, tidak ada jaringan internet di rumah dan kapasitas telepon genggam yang digunakan sebagai sarana belajar tidak memadai, sehingga di saat menggunakan aplikasi seperti google classroom harus menghapus aplikasi yang lain supaya bisa mengikuti pembelajaran jarak jauh.
\end{abstract}

Kata kunci : Kesulitan belajar, matematika SMP, Pembelajaran daring.

\section{PENDAHULUAN}

Sekolah Menengah Pertama (SMP) adalah salah satu jenjang pendidikan tingkat dasar. Pendidikan dasar bertujuan untuk memberikan bekal kemampuan dasar kepada peserta didik untuk mengembangkan kehidupannya sebagai pribadi, anggota masyarakat, warga negara dan anggota umat manusia serta mempersiapkan peserta didik untuk mengikuti pendidikan menengah. (PP No.28 tahun 1990 tentang Pendidikan dasar). Selama masa pandemi ini, pembelajaran diselenggarakan secara daring, tentunya butuh penyesuaian bagi peserta didik. Ini disebabkan pembelajaran yang selama ini diadakan di sekolah secara tatap muka (luring) harus berganti menjadi pendidikan secara daring. Pembelajaran secara daring yang dilaksanakan sejak awal tahun 2020 mengakibatkan hasil belajar matematika secara umum cenderung menunjukan hasil yang kurang memuaskan ( dilihat dari hasil penilaian akhir tahun ). Pembelajaran daring atau yang dikenal dengan istilah E-learning merupakan pembelajaran yang memanfaatkan teknologi. Menurut Rosenberg dalam jurnal (Ucu dkk., 2018) e-learning merujuk pada penggunaan teknologi internet dalam mengirimkan serangkaian solusi yang mampu meningkatkan pengetahuan dan keterampilannya. Sedangkan menurut Sutabri dalam jurnal (Agusli \& Azianah, 2014) menyatakan bahwa e-learning merupakan cara terbaru dalam proses belajar mengajar, e- learning lebih merujuk kepada pembelajaran yang di dukung melalui web sehingga dapat dilakukan didalam kelas sebagai pendukung pengajaran tradisional, dalam mengakses e-learning dapat dilakukan baik itu di rumah atau di dalam ruang kelas, juga dapat dilakukan dalam ruang kelas virtual, dimana semua kegiatan dilakukan online. 
Pembelajaran secara daring memungkinkan siswa untuk mempelajari hal-hal baru dengan mudah karena dapat memperoleh visualisasi sehingga pembelajaran menjadi penting.

Mendengar kata-kata matematika membuat sebagian siswa merasa tidak senang karena mereka menganggap matematika adalah mata pelajaran yang membuat mereka harus banyak mengeluarkan energi untuk berpikir. Itu disebabkan mereka belum menemukan konsep belajar matematika yang sesungguhnya. Matematika adalah salah satu mata pelajaran yang memerlukan pemahaman karena matematika bukan hanya hafalan.

Menurut Susanto (2013: 183) Matematika merupakan ide-ide yang abstrak yang berisi simbol-simbol.matematika adalah ilmu yang harus dipahami. Sehingga dengan belajar matematika siswa dapat melakukan penalaran untuk dapat memahami pembelajaran matematika Kesulitan belajar matematika pada siswa sekolah menengah adalah merupakan kesulitan belajar akademik (Suryani 2012) yang bisa disebabkan oleh beberapa factor diantaranya faktor internal dan faktor eksternal. Kesulitan belajar (learning disability) lebih banyak terjadi setelah pembelajaran secara daring dilaksanakan,hal ini terlihat dari penilaian terhadap tugas yang diberikan kepada siswa.

Dalam pembelajaran matematika secara daring tentunya berdampak yang cukup besar pada perkembangan cara belajar siswa, yaitu pola belajar yang harus berubah total dari tatap muka dimana siswa dapat bertanya secara langsung dan guru menerangkan materi lalu harus berubah menjadi pembelajaran daring dengan cara beragam.

Penelitian ini dilakukan dengan maksud untuk menganalisis penyebab dari kesulitan belajar Matematika secara daring yang dialami siswa kelas 8 di SMP Negeri 202 Jakarta, sehingga membuat hasil belajar tidak maksimal. Ini terlihat dari hasil belajar saat Penilaian Akhir Tahun (PAT). Hasil penelitian ini akan dijadikan evaluasi untuk memperbaiki proses pembelajaran berikutnya sehingga hasil belajar siswa dapat melampaui nilai kkm.

Dengan diadakannya penelitian ini diharapkan akan dapat dijadikan acuan dalam mengatasi kesulitan belajar matematika secara daring terhadap hasil belajar peserta didik di SMPN 202 Jakarta sehingga untuk ke depannya diharapkan penilaian hasil belajar peserta didik dapat melampaui nilai $\mathrm{kkm}$. Selain itu permasalahan yang dihadapi oleh peserta didik selama belajar daring di masa pandemi covid 19 ini dapat dijadikan pedoman dalam merencanakan strategi pembelajaran selanjutnya dan dapat dimanfaatkan untuk memperbaiki proses pembelajaran secara daring terhadap hasil belajar peserta didik di SMPN 202 Jakarta.

\section{METODE PENELITIAN}

Penelitian ini menggunakan desain penelitian deskriptif kuantitatif dengan metode survey. Penelitian kuantitatif bertujuan untuk melakukan pengukuran dalam melihat hubungan yang fundamental antara pengamatan empiris dengan hasil data secara kuantitatif. Pada penelitian ini peneliti akan melakukan survey dengan memberikan pertanyaan yang sama kepada setiap siswa yang dijadikan sampel pada penelitian ini. Populasi dalam penelitian ini adalah kelas 8 SMP Negeri 202 Jakarta. Mengingat populasinya ada delapan kelas,maka peneliti memilih peserta didik kelas 8A dan 8B SMP Negeri 202 Jakarta sebagai sampel.

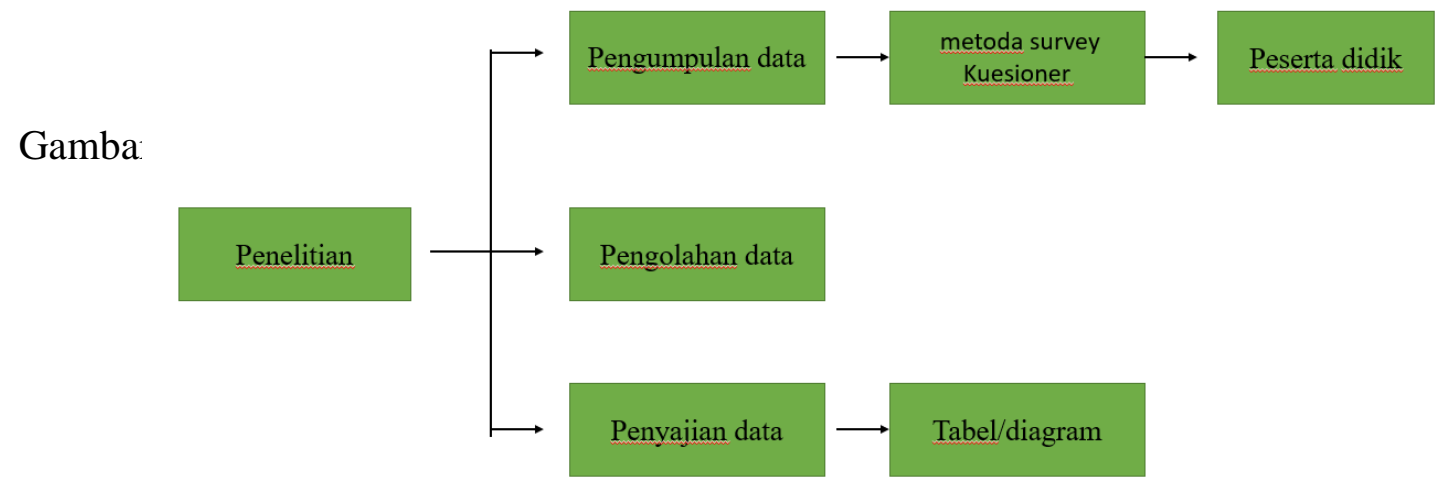

Gambar 1. Alur penelitian 
Dalam memperoleh data tentang tingkat kesulitan belajar matematika secara daring, maka untuk pengumpulan data dalam penelitian ini dengan cara pengisian angket terhadap sampel yang ada. Instrumen penelitian berupa pertanyaan yang dibuat dalam bentuk google formulir yang disampaikan kepada siswa melalui wali kelas dan rekan sejawat peneliti. Analisis data yang didapatkan akan digunakan untuk mendeskripsikan hasil dari penelitian ini. Berikut adalah deskripsi dari angket/kuesioner yang diberikan kepada peserta didik.

\section{HASIL DAN PEMBAHASAN} penelitian.

Berikut adalah kuesioner yang diberikan kepada peserta didik yang menjadi objek

Tabel 1. Deskripsi angket yang diberikan kepada peserta didik

\begin{tabular}{|l|l|l|l|}
\hline No & Deskripsi & \multicolumn{2}{l|}{ Tanggapan } \\
\cline { 3 - 3 } & & Ya & $\begin{array}{l}\text { Tida } \\
\mathrm{k}\end{array}$ \\
\hline 1 & Matematika merupakan pelajaran yang saya sukai & & \\
\hline 2 & Saya merasa kesulitan dalam belajar matematika & & \\
\hline 3 & Matematika merupakan pelajaran yang sulit dipahami & & \\
\hline 4 & Belajar matematika secara daring lebih menyenangkan & \\
\hline 5 & $\begin{array}{l}\text { belajar matematika secara daring lebih sulit dari pada secara luring } \\
\text { (tatap muka) }\end{array}$ & & \\
\hline 7 & Sarana belajar daring yang digunakan adalah handphone & \\
\hline 8 & Sarana belajar daring yang digunakan adalah laptop(computer) & & \\
\hline 9 & Menggunakan buku paket sebagai pedoman belajar daring & & \\
\hline 10 & Ada jaringan wifi di rumah sebagai sarana belajar daring & \\
\hline 11 & Menggunakan kuota sebagai sarana belajar daring & \\
\hline 12 & Ditemani orangtua saat belajar matematika secara daring & \\
\hline 13 & Ditemani kakak saat belajar matematika secara daring & \\
\hline 14 & Membutuhkan teman untuk diskusi untuk belajar matematika & & \\
\hline 15 & Sering bertanya kepada guru ketika kesulitan belajar matematika & & \\
\hline 16 & Suasana rumah menyenangkan untuk belajar & & \\
\hline 17 & Mempelajari materi sebelum mengerjakan tugas/soal latihan & & \\
\hline 18 & Suka mempelajari materi dari youtube yang dibuat guru & \\
\hline 19 & $\begin{array}{l}\text { Suka pembelajaran dengan aplikasi ( google classroom, sway,padlet, } \\
\text { google form,dll) }\end{array}$ & & \\
\hline 20 & Belajar tatap muka lebih disukai dari pada belajar secara daring & & \\
\hline
\end{tabular}

Dari hasil survey diambil lima data terbanyak yang akan disajikan dengan diagram lingkaran dengan menggunakan rumus:

$$
\% \text { Data } \mathrm{A}=\frac{\text { Banyaknya data } A}{\text { Banyak data seluruhnya }} \times 100 \%
$$

Dari penelitian yang dilakukan terhadap 52 peserta didik di dapatkan hasil secara umum yang menunjukkan penyebab kesulitan belajar matematika secara daring yang terbanyak adalah: kesulitan memahami materi, kesulitan belajar jarak jauh, tidak ada ketersediaan jaringan internet (menggunakan data seluler yang cukup kuat menyedot kuota), tidak ada yang mendamping selama belajar dari rumah, tidak mempunyai kapasitas telepon genggam yang memadai. Ini adalah 5 penyebab kesulitan belajar matematika secara daring yang paling banyak dialami siswa kelas 8 SMPN 202 Jakarta 
Penyebab kesulitan belajar matematika secara daring berdasarkan hasil survey dinyatakan dalam bentuk tabel dan diagram lingkaran adalah berikut:

Tabel 2. Penyebab kesulitan belajar matematika

\begin{tabular}{|c|c|c|c|c|}
\hline $\mathrm{NO}$ & Faktor penyebab & $\begin{array}{l}\text { Jumlah } \\
\text { data }\end{array}$ & Persentase & Keterangan \\
\hline 1 & Kesulitan memahami materi (k1) & 27 & $17,4 \%$ & \\
\hline 2 & Kesulitan belajar jarak jauh (k2) & 30 & $19,4 \%$ & \\
\hline 3 & $\begin{array}{l}\text { Tidak ada pendamping dalam belajar } \\
\text { sebagai teman diskusi ( } \mathrm{k} 3 \text { ) }\end{array}$ & 27 & $17,4 \%$ & \\
\hline 4 & Tidak tersedia jaringan internet $(\mathrm{k} 4)$ & 31 & $20,0 \%$ & \\
\hline 5 & $\begin{array}{l}\text { Kapasitas telepon genggam yang } \\
\text { tidak memadai }(\mathrm{k} 5)\end{array}$ & 40 & $25,8 \%$ & \\
\hline
\end{tabular}

\section{FAKTOR PENYEBAB KESULITAN BELAJAR}

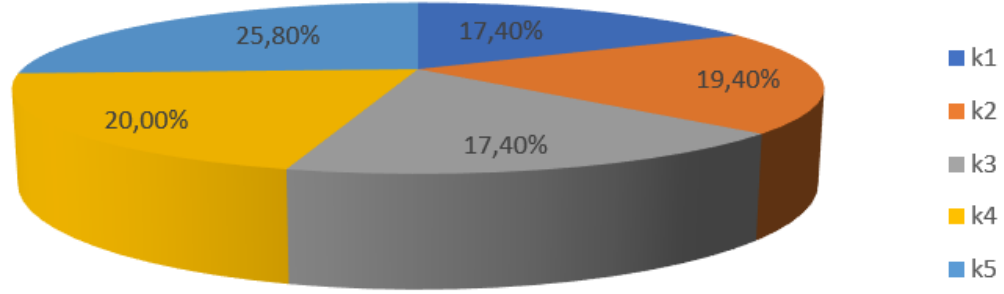

\section{Gambar 2. Diagram Kesulitan Belajar Secara Daring}

Dari diagram dapat dilihat tingkat kesulitan belajar secara daring yaitu: Kesulitan memahami materi (k1) 17,4\%, Kesulitan belajar jarak jauh (k2) 19,4\%, Tidak ada pendamping dalam belajar sebagai teman diskusi (k3) 17,4\%, Tidak tersedia jaringan internet (k4) 20,0\%, dan Kapasitas telepon genggam yang tidak memadai (k5) 25,8\%.

Kesulitan belajar menurut Mulyadi (2010) kesulitan belajar merupakan suatu kondisi dalam proses belajar yang ditandai adanya hambatan-hambatan tertentu untuk mencapai hasil belajar. Senada juga disampaikan oleh Subini (2016) kesulitan belajar merupakan suatu kondisi dimana kompetensi atau prestasi yang dicapai tidak sesuai dengan kriteria standar yang telah ditetapkan, baik berbentuk sikap, pengetahuan, maupun keterampilan.

Kesulitan belajar adalah suatu kelainan yang membuat individu yang bersangkutan sulit untuk melakukan kegiatan belajar yang efektif. Kesulitan dalam memahami materi matematika dalam pembelajaran secara daring dialami siswa setidaknya disebabkan 3 kelemahan, yaitu: Kognitif, Intelegensi, dan Kesiapan Belajar:

\section{Kelemahan kognitif}


Kemampuan kognitif adalah kemampuan tentang penguasaan pengetahuan dan teknologi Menurut Rosyidi (2005) bahwa faktor-faktor menyebabkan siswa mengalami kesulitan belajar ada dua segi yaitu segi kognitif dan segi non kognitif. Segi kognitif meliputi halhal yang berhubungan dengan kemampuan intelektual siswa dan cara siswa memproses atau mencerna materi matematika dalam pikirannya. Sedangkan segi bukan kognitif adalah semua faktor diluar hal-hal yang berhubungan dengan kemampuan intelektual seperti sikap, kepribadian, cara belajar, kesehatan jasmani, keadaan emosional, cara mengajar guru, fasilitas-fasilitas belajar, serta suasana rumah

2. Kemampuan intelegensi

Menurut David Wechsler intelegensia adalah kemampuan bertindak secara terarah,berpikir secara rasional dan menghadapi lingkungan secara efektif. Secara garis besar dapat disimpulkan bahwa intelegensi adalah kemampuan mental yang melibatkan proses berpikir secara rasional. Dengan kata lain intelegensi adalah kemampuan berpikir secara rasional. Menurut Marbun(2018) factor-faktor yang mempengaruhi intelegensi adalah factor bawaan atau keturunan dan factor lingkungan.

\section{Kemampuan dalam kesiapan belajar}

Menurut Marbun (2018) perbedaan latar belakang kehidupan yang meliputi perbedaan sosial ekonomi akan mempengaruhi kesiapan dalam belajar setiap anak. Akibatnya anak dengan umur yang sama tidak selalu memiliki kesiapan yang sama dalam belajar.

Menurut Subini (2016) bahwa faktor yang mempengaruhi kesulitan belajar adalah faktor internal dan eksternal. Kelemahan kognitif, intelegensi dan kesiapan belajar merupakan factor internal yang dialami oleh peserta didik di SMPN 202 Jakarta.Kondisi belajar daring, bagi sebagian peserta didik terasa menyenangkan karena dalam pembelajaran ini guru memberikan pembelajaran yang bervariasi dengan aplikasi-aplikasi, dengan tatap muka secara online, dengan video yang dapat diulang bahkan memberikan soal latihan juga dengan aplikasi, tapi bagi sebagian lagi peserta didik tetap saja pembelajaran tatap muka menjadi harapan hampir sebagian besar siswa. Hal ini disebabkan dengan pembelajaran tatap muka lebih mudah untuk komunikasi secara langsung ketika siswa ada kendala dalam pembelajaran.

Kesulitan pembelajaran jarak jauh tentunya dialami oleh setiap siswa karena perubahan cara belajar. Siswa butuh adaptasi dalam belajar apalagi bagi siswa yang selama ini kurang menguasai teknologi harus bisa menyesuaikan dengan kondisi saat ini. Ketersediaan jaringan di rumah dapat juga menjadi hambatan dalam pembelajaran secara daring karena siswa tidak dapat leluasa menggunakan sarana belajar dengan leluasa. Selain itu kapasitas telepon genggam yang dipakai siswa dalam belajar daring juga menentukan kesulitan dalam belajar karena aplikasi yang digunakan oleh guru dlam pembelajaran membutuhkan penyimpanan data yang cukup besar. Bagi siswa yang orangtuanya bekerja dan tidak ada yang mendampingi dalam belajar matematika tentunya menjadi salah satu hambatan dalam belajar sehingga menimbulkan kesulitan dalam belajar matematika di rumah.

Jadi kesulitan belajar matematika secara daring yang dialami siswa kelas 8 SMP Negeri 202 Jakarta disebabkan oleh factor internal dan factor eksternal. Dengan diketahuinya kesulitan belajar matematika secara daring, maka peneliti akan mencoba melakukan perubahanperubahan dalam pembelajaran berbentuk lebih memperbanyak tatap muka secara daring, pemberian materi melalui video pembelajaran, komunikasi melalui wag secara langsung dengan peserta didik dan meningkatkan kerja sama dengan guru BK dan wali kelas.

\section{KESIMPULAN}

Berdasarkan hasil penelitian “Analisis Tingkat Kesulitan Belajar Matematika Secara Daring" dapat disimpulkan bahwa terdapat beberapa factor yang menyebabkan sebagian hasil belajar akademik siswa kurang memenuhi standar. Didapatkan tingkat kesulitan yang cukup tinggi yang berasal dari factor internal berasal dari diri sendiri yaitu kurang kemampuan memahami materi dengan baik yang disebabkan rendahnya kemampuan kognitif,intelegensi 
dan kurang siap untuk menghadapi pembelajaran dan factor eksternal berasal dari keluarga,lingkungan, sarana dan prasarana.

\section{DAFTAR PUSTAKA}

Abdullah M. (2015). Metode Penelitian Kuntitatif. Yogyakarta : Aswaja Pressindo

Abdur Rahman, dkk. (2017). Buku Paket Matematika kelas 8. Kemendikbud

Anshori M., Sri Iswati. (2009). Buku Ajar Metodologi Penelitian. Unair.

Agusli dan Azianah. (2014). "Implementasi E-Learning Berbasis Web di SD Negeri Pasarkemis 1." Jurnal Sisfotek Global 4.

Hajar Ibnu. (2014). Dasar-dasar Statistika. Pustaka Zaman.

Hidayati.T. (2019). Statistika Dasar. CV Pena Persada.

Jamal, F. (2014). Analisis Kesulitan Belajar Siswa Dalam Mata Pelajaran Matematika Pada Materi Peluang Kelas XI IPA SMA Muhammadiyah Meulaboh Johan Pahlawan. Jurnal MAJU (Jurnal Pendidikan Matematika), 1(1) : 18-36.

Marbun S . (2018). Psikologi Pendidikan. Ponorogo : Uwais Inspirasi Indonesia.

Morrisan, MA. (2012). Metodologi Penelitian Survey. Kencana.

Mulyadi. (2010). Diagnosis Kesulitan Belajar Dan Bimbingan Kesulitan Belajar Khusus. Yogyakarta : Nuha Litera.

Rosyidi, A. (2005). Analisis Kesalahan Siswa Kelas II MTs Alkoiriyah dalam Menyelesaikan Soal Cerita Terkait Persamaan Linear Dua Peubah. Thesis. Surabaya.

Subini N. (2016). Mengatasi Kesulitan Belajar Pada Anak. Yogyakarta : Buku Kita.

Peraturan pemerintah no 28 tahun 1990 tentang Pendidikan dasar

Suryani. (2012). Kerjasama Orangtua Dengan Guru Pembimbing Dalam Mengatasi Kesulitan Belajar. Jurnal Ilmiah

Ucu,dkk. (2018). Analisa Pemanfaatan E-Learning Untuk Proses Pembelajaran. Manado: Jurnal Universitas Sam Ratulangi.

Urbayatun, S. (2019). Kesulitan Belajar Dan Gangguan Psikologi Ringan Pada Anak. K Medina

Yusuf A, M. (2014). Metodologi penelitian. Kencana. 